\title{
ІСТОРІЯ ТА ПРОБЛЕМИ СТАНОВЛЕННЯ ІНСТИТУТУ РЕСТИТУЦЇ КУЛЬТУРНИХ ЦІННОСТЕЙ НА ТЕРИТОРІЇ УКРАЇНИ
}

\begin{abstract}
Анотація. Україна - країна з тисячолітньою історіею. Кожний етап розвитку від трипільців до сьогодні несе за собою важливі події, політичні особливості, економічні злети і падіння, а також культурну спадщину. За свою історію Україна боролась за незалежність від країн-сусід, доводила свою ідентичність та намагалась створити окрему державу. Від заснування Києва (482 р.) до сьогодні пройшло 1539 років, $30 з$ яких Україна є незалежною країною. Цілком логічно, що ці 30 років українці намагаються відновити історію держави, вживають заходів для збереження будь-яких речових, писемних пам'яток та збирають, мов 3 пазлів повний хронологічний історичний шлях, який пройшла Україна. Музейні надбання, виставки, бібліотеки, приватні колекції мають багато незаповнених місць і не через те, що втрачені пам'ятки та цінності не можна вже відновити. По всьому світу у музеях можна віднайти клаптики української історії, проте, рано чи пізно, але кожна реліквія, кожна пам’ятка має повернутись на Батьківщину - до України. 24 серпня 2021 року в урочистій промові до Дня Незалежності Президент Володимир Зеленський проголосив: «Ми будемо повертати не тільки своїх, ми будемо повертати своє - це історичні і культурні цінності нашої держави, що перебувають за кордоном. Ми більше ніколи і нікому не подаруємо жодний камінчик нашої історії, ми не дамо окуповувати жодну сторінку нашої історії...». За 30 років незалежності було здійснено безліч маленьких кроків для повернення культурних цінностей - створювались органи, започатковувались реєстри, локальні проекти займались глобальною місією - повернення історії. Проте, органи закривали, реєстри не вели, а локальні проекти так і залишались на сторінках газет. Роботи у напрямі повернення культурних цінностей дуже багато, адже фактично з нуля необхідно будувати новий орган та нормативну базу, адже наразі це питання регулює один закон, а наявний орган, який би займався пошуком та поверненням втрачених пам'яток не проводить жодних дій у цьому напрямі.
\end{abstract}

Ключові слова: реституція, повернення, культурні цінності, дипломатія, державна політика.

Myrhorod-Karpova Valeria, Koroshchenko Kateryna

Sumy State University

\section{HISTORY AND PROBLEMS OF FORMATION OF THE INSTITUTE OF RESTITUTION OF CULTURAL VALUES ON THE TERRITORY OF UKRAINE}

Summary. Ukraine is a country with a thousand-year history. Each stage of development from Trypillia to the present day bears for its respective event, political features, economic ups and downs, as well as cultural heritage. Throughout its history, Ukraine has fought for independence from neighboring countries, proved its identity and tried to create a separate state. 1539 years have passed since the founding of Kyiv (482), 30 of which Ukraine is an independent country. It is quite logical that for these 30 years Ukrainians have been trying to restore the history of the state, living up to measures to preserve any material and written monuments, and collecting, like puzzles, the complete chronological historical path that has passed through Ukraine. Museums, exhibitions, libraries, private collections have a lot of unfilled places and not because the lost monuments and value can not be restored. Pieces of Ukrainian history can be found in museums all over the world, however, sooner or later, but every relic, every monument must return to the Motherland - to Ukraine. On August 24, 2021, in a solemn speech dedicated to the Independence Day, President Volodymyr Zelensky proclaimed: "We will return not only our own, we will return our own - these are the historical and cultural values of our state abroad. We will never give a single stone of our history to anyone again, we will not let a single page of our history pay off...». During the 30 years of independence, a local number of small steps have been taken to restore cultural values - creating bodies, establishing registers, engaged in a global mission - the return of history. However, they did not keep registers, and local projects remained on the pages of newspapers. There is a lot of work to restore cultural values, because in fact it is necessary to build a new body and regulatory framework from scratch, as this issue is currently regulated by one law, the existing body that searches for and returns lost monuments does not take any action.

Keywords: restitution, return, cultural values, diplomacy, state policy.

$\Pi$ остановка проблеми. Причиною для зупинення усіх можливих продуктивних процесів з приводу запущення процесу реституції культурних цінностей слугувало нестача фінансування, політичні інтриги, а також дипломатичні поступки. У результаті Україна не має фрункціонуючого державного органу, яка б займалась поверненням втрачених культурних пам'яток. У будь-якому випадку створення нового органу відбудеться, проте необхідно визначити недоліки минулого для побудови майбутнього.
Аналіз останніх публікацій та досліджень. У сучасній науці цьому питанню приділили увагу такі науковці, як М. М. Богуславський, А. В. Гайдашов, Л. Н. Галенська, Уве Гартманн, Патриція Грімстед Кеннеді, Мальгожата А. Квінкенштейн, С. I. Кот, T. М. Себта, Н. П. Українець, О. К. Федорук, М. М. Яцишин та інші дослідники.

Мета статті. Актуальність ціеї теми змушує згадати історію органів, які займались поверненням культурних цінностей та визначити основні 
досягнення, які можна взяти на майбутне та недоліки, яких не можна повторювати.

Виклад основного матеріалу дослідження. Державне регулювання у сорері повернення культурних цінностей в Україні пройшло декілька етапів та результати їх діяльності можна побачити в українських музеях. Діяльність цих органів проходила досить активно.

В Україні за весь час незалежності існували такі органи:

1. Національна комісія з питань повернення в Україну культурних цінностей (1992-1999рр.).

2. Державної служби контролю за переміщенням культурних цінностей через державний кордон (2000-2011 рр.).

Як тільки Україна стала незалежною питання про повернення культурних цінностей стало на порядок денний, тому рішенням Уряду держави 28 грудня 1992 р. була створена Нащіональна комісія з питань повернення в Україну культурних цінностей.

Відтак, Уряд ухвалив постанову «Про Національну комісію з питань повернення в Україну культурних цінностей» від 05.10.1996 р. № 48 [1]

Важливість створення Національну комісію 3 питань повернення в Україну культурних цінностей влучно описав мистецтвознавець О. К. Федорук у статті «Національні святині. Час повернення». Автор зазначає, що схожі комісії функціонують майже в кожній країні, які були учасниками Другої світової війни. А також перед комісією, яка створилась в Україні дуже великий пласт роботи, а саме: складання повного реєстру наявних та втрачених культурних цінностей, а також визначення їх унікальності в контексті європейської світової культури [2].

Законодавещь влучно описав основні напрями діяльності новоствореного органу, зокрема:

- займатись пошуком тих культурних цінностей, які визнані експертами втраченими;

- здійснювати захист національних інтересів, які стосуються культурних цінностей, що належать українцям за кордоном;

- оголошувати в розшук пам'ятки, які визнані втраченими [2].

Указом Президента України від 26 липня 1996 р. № 596 «Про зміни в системі центральних органів виконавчої влади України» Національну комісію було підпорядковано Міністерству культури і мистецтв України [2].

Вважаю за доцільне звернути увагу на позицію доктора юридичних наук В. І. Акуленко та голови підкомісії Комісії ВРУ з питань культури і духовності М. Г. Жулинського щодо підпорядкуванню Національної комісії 3 питань повернення в Україну культурних цінностей колишньому Міністерству культури і мистецтв України. Зазначимо, що вся інтелігенщія тоді виступила проти цих змін, бо люди розуміли, який нищівний результат це може мати.

В. I. Акуленко зазначає, що тільки з утворенням Національної комісії з питань повернення в Україну культурних цінностей у 1993 році стала формуватись політика України з приводу повернення культурних цінностей і вже почали вживатись реальні заходи. Оскільки, Національна комісія з питань повернення в Україну культурних цінностей переведено до складу Мінкуль- тури, це матиме такий результат у якому зміст тексту завдань цього органу суттево зміниться та роль повернення культурних цінностей дуже принижується [3].

На сесійному засіданні 21 лютого 1997 p. М. Г. Жулинський підкреслив статус Національної комісії повернення культурних цінностей в Україну, а саме те, що діючи самостійно, комісія тісно співпрацювала 3 іншими органами і з Міністерством культури, і з Головним архівним управлінням, проте на сьогоднішній день статус самостійного органу змінено на статус підпорядкованого [4].

За свою діяльність Нащіональна комісія з питань повернення в Україну культурних цінностей мав досить позитивні результати. Одним 3 напрямків діяльності органу була співпраця з українською діаспорою, ця співпраця мала як результат повернення творів Грищенка, хореографрічну й кінематографічну спадшину у творах Василя Авраменка. Архівні матеріали Галини Мазуренко, Віктора Некрасова, Олеся Ольжича та інших. Національну комісію з питань повернення в Україну культурних цінностей почав виконувати своє завдання створення банків втрачених пам'яток, було створено «Каталог втрачених експонатів Національного музею у Львові», каталоги «Бібліотечні фонди Харкова в роки Другої світової війни», «Фонди втрат Волинського музею» тощо [1].

Постановою Кабінету Міністрів України «Про утворення Державної служби контролю за переміщенням культурних цінностей через державний кордон» № 221 від 7 лютого 2000 р. Національну комісію з питань повернення в Україну культурних цінностей було ліквідовано. Передбачалось, що Державна служба контролю функціонуватиме як урядовий орган державного управління у copeрі контролю за вивезенням, ввезенням та поверненням культурних цінностей у складі Міністерства культури і мистецтв [5].

Повноваження та завдання були схожі з Національною комісією 3 питань повернення культурних цінностей, окрім того, що Державна служба контролю за переміщенням культурних цінностей через державний кордон контролю самостійно ухвалювала рішення щодо можливого вивезення культурних цінностей, видавала свідоцтва на право вивезення культурних цінностей, складала переліки культурних цінностей, що вивозяться, а також встановлювала порядок тимчасового вивезення [5].

Варто відзначити, що окрім активної діяльності 3 приводу контролю над вивезення культурних цінностей державна служба здійснювала процеси повернення культурних та історичних цінностей.

Результати діяльності органу з питання повернення культурних цінностей є також суттєвими в період з 2000-2011 рік було повернуто близько 150 тисяч архівних матеріалів, наприклад: колекції історика Солов'я Д., поетеси Вовк В., археолога Курінного П., художника Михайліва Ю., також архіви родини гетьмана Скоропадського П. [5].

Українські культурні цінності передавались на Батьківщину із країн Європи (Німеччини, Франції, Чехії, Швейцарії, Словаччини, Росії, Великої Британії, Естонії), країн Північної та Південної Америки (США, Канади, Венесуели, Бразилії) та Австралії [5]. 
У 2011 р. на виконання Указу Президента України від 9 грудня 2010 р. № 48 «Про оптимізацію системи центральних органів виконавчої влади» Кабінет Міністрів України приймае постанову, якою було ліквідовано Державну службу контролю за переміщенням культурних цінностей через державний кордон. На даний час фуункції контролю за вивезенням, ввезенням та поверненням культурних цінностей виконуе Міністерство культури України [5].

Історія системи адміністративного регулювання питання повернення культурних цінностей налічуе два органи, які мають успішні результати своеї діяльності. Національна комісія з питань повернення культурних цінностей співпрацювала 3 українською діаспорою та проводила активну реституційну політику. Державна служба контролю за переміщенням культурних цінностей через державний кордон проводила реституційну політику і нагляд за тим, які культурні цінності з України вивозились. Вважаю, що діяльність органів, які займаються питанням повернення культурних цінностей була дуже важливою для української спадщини. Необхідно скористатись позитивним досвідом цих органів при створенні нового.

Аналізуючи історію органів, які займались поверненням культурних цінностей необхідно взяти позитивний досвід та перенести у сьогодення. Створення оновленого державного органу, а саме: Державної служби з питань повернення культурних цінностей та історичних пам'яток може відновити галузь та мати вагомі результати.

Перш за все, зауважимо, що пошук та повернення культурних цінностей повинен відокреми- ти поняття: культурні та історичні цінності. До культурних цінностей варто віднести все те, що має важливу роль для доповнення культурної спадщини України, а історичні цінності - всі ті об’екти, які мають важливе значення для дослідження та вивчення історії нашої країни.

По-друге, це часові обмеження пошуку культурних цінності - не тільки за період Другої світової війни, як зазначається у багатьох нормативних документах, а за весь час поки Україна стала на міжнародній арені як самостійна держава. Тому що вивіз національних цінностей відбувався не тільки декілька років, а декілька століть.

Державний орган з питань повернення культурних та історичних цінностей повинен мати три напрями діяльності:

- пошук;

- перемовини;

- повернення.

Визначені важливі моменти функціонування це запорука для успішного функціонування Державної служби з питань повернення культурних та історичних цінностей. Новостворена установа матиме три напрями діяльності: пошук, перемовини, поверненням з залученням істориків, етнографрів, дипломатів. Тільки здійснюючи свою діяльність послідовно можна досягти того, щоб повернути культурні цінності. Для цього необхідне створення Реестру втрачених культурних цінностей, якісні кадри, нормативна база, яка чітко прописуе діяльність служби та визначае важливість повернення на історичну батьківщину всіх цінностей.

Висновки. Отже, після проголошення Президентом України напрямку на повернення культурних цінностей почнеться активна робо-

\section{Державна служба з питань повернення культурних цінностей та історичних пам'яток \\ Таблиця 1}

\begin{tabular}{|c|c|}
\hline $\begin{array}{c}\text { Комісія з питань } \\
\text { пошуку }\end{array}$ & $\begin{array}{l}\text { Робота комісії прямо пов'язана з Реєстром втрачених цінностей. Саме на цьому етапі } \\
\text { кращі фахівці мають працювати над тим, щоб досліджувати, що було втрачено } \\
\text { за століття обкрадання України. } \\
\text { Тут обов'язкова співпраця з обласними архівами та регулярні відрядження до міст } \\
\text { з метою спілкування з місцевими краєзнавцями, які володіють більш розширеною } \\
\text { інформацією про втрачені пам'ятки. } \\
\text { На робітників цього процесу покладається також уточнення інформації, } \\
\text { де знаходиться пам'ятка. Важливо, щоб були організовані експедиції та пошукові } \\
\text { групи до інших країн, аби чітко розуміти де зберігається історична цінність. }\end{array}$ \\
\hline $\begin{array}{l}\text { Комісія з питань } \\
\text { перемовин }\end{array}$ & $\begin{array}{l}\text { Комісія займається перемовинами з іншою стороною, у якої знаходиться історична } \\
\text { пам'ятка. На робітників етапу діалогу покладається організація зустрічей з } \\
\text { представниками іншої країни, де на основі чітких фактів доводиться те, що обєкт } \\
\text { е українським. Учасники етапу діалоги - дипломати, юристи, історики, етнографи, } \\
\text { робітники музейної справи. }\end{array}$ \\
\hline $\begin{array}{l}\text { Комісія з питань } \\
\text { повернення }\end{array}$ & $\begin{array}{l}\text { Вичерпний перелік осіб з комісії відправляються у відрядження для того, } \\
\text { аби забрати пам'ятку, яка визнана української. } \\
\text { Важливо, щоб були присутні дипломати, юристи та історики, які будуть представляти } \\
\text { Україну на належному рівні, а також необхідно дотримуватись чітких вимог, щоб } \\
\text { транспортувати пам'ятку належним чином на територію Україну, не пошкодивши ії. }\end{array}$ \\
\hline $\begin{array}{l}\text { Комісія, яка має } \\
\text { надавати } \\
\text { чи не надавати дозвіл } \\
\text { на вивезення }\end{array}$ & $\begin{array}{l}\text { Комісія здійснюе багатоетапну перевірка цінності, а також обов'язковий пошук } \\
\text { у Реєстрі втрачених культурних цінностей та у випадку схожості не надавати } \\
\text { дозволу на вивезення. Також цінність, яку подає громадянин, який звертається } \\
\text { з клопотанням про надання дозвіл на вивезення, має бути зареєстрована у Реєстрі } \\
\text { нерухомих культурних цінностей. }\end{array}$ \\
\hline $\begin{array}{c}\text { Контролери, які } \\
\text { займаються контролем } \\
\text { над тимчасово } \\
\text { вивезеними пам'ятками }\end{array}$ & $\begin{array}{l}\text { Уповноважені особи, які супроводжують вивезені пам'ятки та здійснюють повний } \\
\text { контроль над тим, як культурній цінність охороняють та дотримуються всіх } \\
\text { попередніх домовленостей. }\end{array}$ \\
\hline $\begin{array}{c}\text { Комісія з виявлення } \\
\text { підробок }\end{array}$ & $\begin{array}{l}\text { Виявлення оригіналом чи підробкою повернулась культурна цінність на територію } \\
\text { України має спеціальна комісія з виявлення підробок, яка б займалась повною } \\
\text { експертизою культурної цінності. }\end{array}$ \\
\hline
\end{tabular}

Джерело: складено авторами на основі власних досліджень 
та з приводу модернізації наявного органу. Для успішної роботи необхідне достойне орінансування та чітке адміністративне регулювання.

Архіви істориків, поетес, художників, політичних діячів знаходяться у десятках країн, цей спа- док є неоціненним вкладом у культурну спадщину України, пошук та повернення - $є$ нашим свідомим обов'язком, виконання його стане підтвердженням того, що український народ $є$ небайдужим до минулого предків та майбутнього нащадків.

\section{Список літератури:}

1. Українець Н.П. Проблема повернення в Україну культурних цінностей. Сучасна украӥнська політика. Політики і політологи про неї. 2010. № 19. С. 279-287.

2. Федорук О.К. Національні святині. Час повернення. Вісті з Украӥни. 1993. № 34. С. 166-168.

3. Центральний державний архів вищих органів влади та управління. Ф. 1. Оп. 22. Спр. 4640. Арк. 70-72.

4. Центральний державний архів вищих органів влади та управління. Ф. 1. Оп. 42. Спр. 215. Арк. 63.

5. Кулініч М. Ю. Архівна україніка і діяльність Державної служби контролю за переміщенням культурних цінностей через державний кордон України (2000-2011рр.): короткі підсумки. Статті та повідоллення. 2011. № 3. C. 11-20.

\section{References:}

1. Ukrainets N.P. (2010) Problema povernennia v Ukrainu kulturnykh tsinnostei [Ukrainian NP The problem of returning to Ukraine cultural values]. Modern Ukrainian politics. Politicians and political scientists about it, no. 19 , pp. 279-287.

2. Fedoruk O.K. (1993) Natsionalni sviatyni. Chas povernennia [National shrines. Return time]. News from Ukraine, no. 34 , pp. $166-168$.

3. Tsentralnyi derzhavnyi arkhiv vyshchykh orhaniv vlady ta upravlinnia. F. 1. Op. 22. Spr. 4640. Ark. 70-72.

4. Tsentralnyi derzhavnyi arkhiv vyshchykh orhaniv vlady ta upravlinnia. F. 1. Op. 42. Spr. 215. Ark. 63.

5. Kulinich M.Yu. (2011) Arkhivna ukrainika i diialnist Derzhavnoi sluzhby kontroliu za peremishchenniam kulturnykh tsinnostei cherez derzhavnyi kordon Ukrainy (2000-2011 rr.): korotki pidsumky [Archival Ukrainian and the activities of the State Service for Control over the Movement of Cultural Property Across the State Border of Ukraine (2000-2011): brief results]. Articles and messages, no. 3, pp. 11-20. 